\section{Which facts, whose life?}

\section{Ruth Hubbard}

The Facts of Life: Science and the Abortion Controversy. By Harold J. Morowitz and James S. Trefil. Oxford University Press: 1992. Pp. 179. \$19.95.

THE anthropologist Rayna Rapp opens a recent article about women's experiences of amniocentesis with this excerpt from an interview with a 39-year-old New York woman:

When we walked into the doctor's office, both my husband and I were crying. [The doctorl looked up and said. "What's wrong? Why are you in tears?" "It's the baby, the baby is going to dic", I said.

"That isn't a baby", he said firmly. "It's a collection of cells that made a mistake.

Clearly, there is a wide divergence in the ways different people perceive pregnancy and its termination. In the abortion debate, opinions range from total support for a woman's right to decide whether to abort and when, to total interdiction. Even among advocates of abortion rights opinions differ. In the heady days of women's liberation some 25 years ago, feminists argued that unless women can avoid unwanted births, they are not free to participate fully in heterosexual relationships. Over the years, the link between abortion and sexuality has been pushed into the closet. Support for abortion rights increasingly focuses on women's need to plan their families and to terminate pregnancies resulting from rape or incest. Different groups draw the line at different stages of pregnancy, although in the United States, most abortion rights advocates support the distinction the Supreme Court established in 1973 in Roe v. Wade. This ruling holds that, during the first two trimesters, abortion is a private matter to be decided by a woman in consultation with her physician. Only in the third trimester, when a fetus can survive outside the womb, may the state regulate abortions, although it need not do so. Increasingly, women's rights activists have accepted the ruling's concerns with privacy and choice, and abandoned the issue of sexual liberation.

In the 20 years since Roe v. Wade, abortion rights in the United States have been narrowed by legislatures and the courts so that it has become increasingly difficult for poor women and young women without supportive parents to obtain abortions. For example, states or the federal government need not pay for abortions of poor women receiving social insurance (Medicaid) or of insured government workers, including women in the military and female dependants of military men. Various states have imposed a requirement that minors obtain parental consent, in some states by both parents, even if they live apart.

Perhaps the most drastic changes in the conditions under which women who need abortions and clinics that provide them must operate have resulted from direct confrontations by opponents of abortion. But here too we must distinguish among different views. Some pacifist and religious groups oppose abortion because they oppose killing humans, and perhaps also animals, under any circumstances. They represent a tiny fraction of that minority of Americans who oppose abortion. The Roman Catholic Church holds that life begins at conception and therefore opposes abortions as murder, although it does not oppose other forms of killing, such as wars or the death penalty. (Incidentally, Catholics have proportionally as many abortions as have women of other religious denominations.) Differences also exist among anti-abortion activists in the radical right. Some groups, usually led by women, focus on women's 'natural' mission as mothers. They lead prayers and vigils, and hail women who decide not to abort despite hardships. By contrast, Operation Rescue is a male-led group that tries to intimidate clients, doctors and other clinic personnel and

In the abortion debate, the New Right do whatever it takes to close clinics down. views on the steps of the US Supreme Court. conceals its anti-feminist agenda of controlling women's lives and especially women's sexuality by championing the unborn'. This obscures the fact that 'the unborn' develops within the body of a woman, a human being who may have needs and intentions that do not include having a baby at that stage in her life, or perhaps ever.

The authors of this book try to ground the abortion debate in modern science. Yet, by focusing on the biology of fertilization and embryonic development, they too leave women out of account. The dilemma they confront is that, as scientists, they acknowledge that a developing fetus is both alive and human. Yet, like most Americans, they support abortion rights up to a point. They solve this dilemma by deciding that, biologically, a fetus is more animal than human until it develops what they call "humanness". And, as they point out, although killing animals may be frowned on, it is not murder. On the basis of a mixture of evolutionary and embryological arguments, they then conclude that humanness is attained when the cerebral cortex becomes recognizably human at around 24 weeks of gestation. Although the authors write with admirable clarity, their argument reads more like a scholastic treatise about 'ensoulment' than the "objective" science that they claim it represents.

The authors assert that specifying humanness provides a scientific way to resolve the abortion question, but their solution is laden with problems. The central one is that they ignore the fact that their scientific views are embedded in cultural beliefs. Many differences, and similarities, exist between humans and

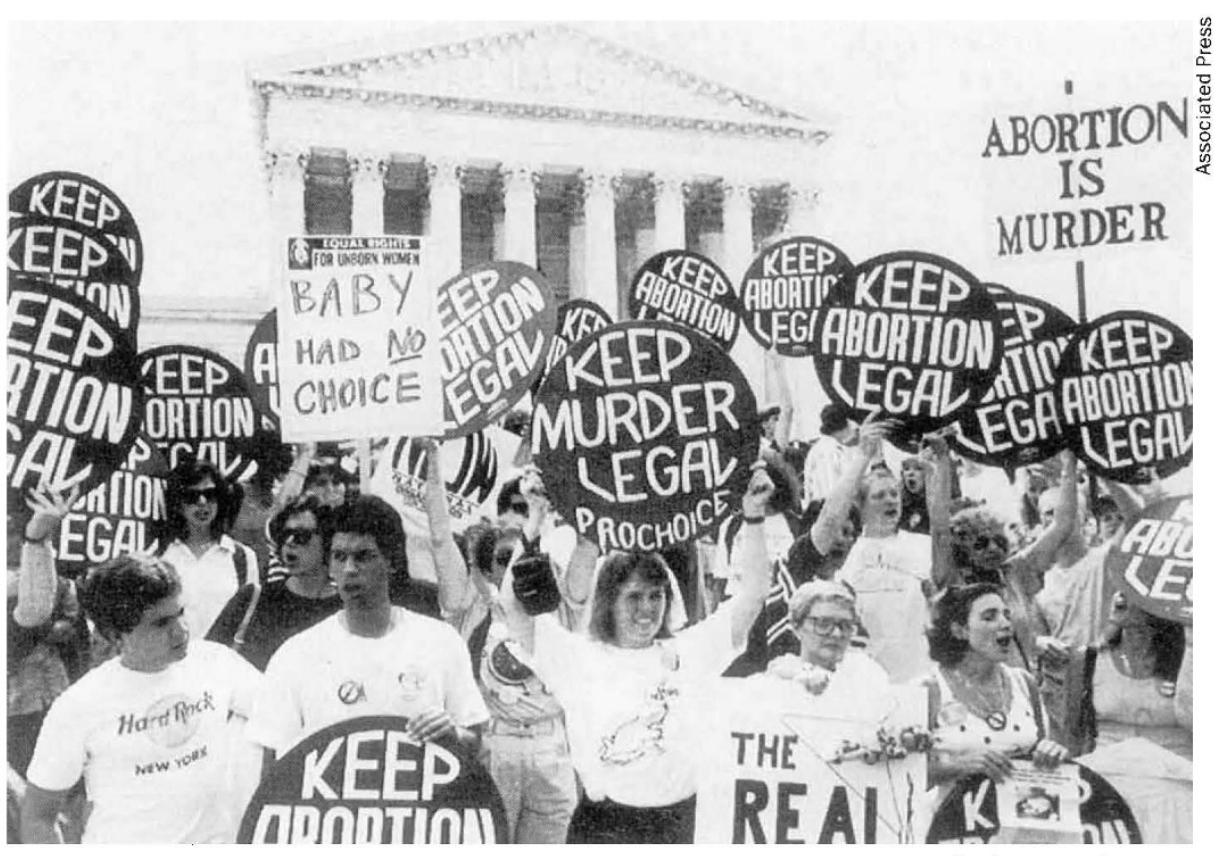

Pregnancy test case - pro-life and pro-choice demonstrators express their opposing

NATURE · VOL 360 - 26 NOVEMBER 1992 
other animals. Assigning a privileged position to the brain is not 'scientific', but is grounded in the mind--body split that dominates our culture. And there is no scientific reason why killing animals is permissible, when killing humans is not. The distinction does not originate in biology or evolution, but is part of the Judaeo-Christian tradition in which God gave humans dominion over the rest of creation. Buddhist and other traditions do not accept it. Finally, the authors finesse a question that is central to the abortion debate when they mention in passing, and without comment, that taking a human life is murder only when it is done "without the sanction of the state" (page 12). This caveat raises the question why the state should forbid abortion when it sanctions killing people convicted of certain crimes, glorifies killing in wartime and permits it in selfdefence. Indeed, why isn't terminating an unwanted pregnancy a form of selfdefence?

Because of their exclusive focus on "the fetus", the authors ignore the fact that, whatever the law says, as long as there are unwanted pregnancies there will be abortions. The important question is whether abortions are legal and safe, or illegal and damage or kill women. Where abortion is legal, it involves fewer risks for women than does a full-term birth. An "objective" book about abortion should consider the effects that gestation, birth and abortion have on women. Scientific information about these topics bears on political decisions about abortion, but this book omits such facts of life.

Ruth Hubbard is in the Department of Cellular and Developmental Biology, Harvard University, Cambridge, Massachusetts 02138, USA.

\section{Responsible genetics}

\author{
Dorothy Nelkin
}

Gene Mapping: Using Law and Ethics as Guides. Edited by George J. Annas and Sherman Elias. Oxford University Press: 1992. Pp. 291. \$39.95.

MORE than two decades ago, the field of study called 'science, technology and society' began systematically to assess the ethical, legal and social implications of science and technology. Sociologists, ethicists and historians during the $1970 \mathrm{~s}$ addressed questions of privacy, distribution and discrimination associated with such technologies as computer databanks and medical diagnostics, research practices such as human experimentation and organ transplantation, and scientific claims such as the relationship between crime and heredity or race and IQ. Most of their studies involved technologies already developed and issues already in dispute. By contrast, the founders of the Human Genome Project decided at the outset to invest at least three per cent of its annual budget in a programme called Ethical, Legal and Social Implications (ELSI).

Gene Mapping includes the papers from a January 1991 workshop convened to outline for ELSI the broad social policy issues that are likely to emerge from genome research. In an introductory essay, James Watson, former head of the genome project, and Eric Juengst, director of ELSI, tell us that genomic research will "provide insights into the treatment and prevention of both inherited disorders and diseases. . . [and] shed light on our evolution as a species and our development as individuals. And it mendations, listing four questions that should shape ELSI's future research priorities. When and how should genetic tests be introduced into medical practice? How can confidentiality of genetic information be preserved? How can discrimination be prevented? How might the genome project affect our concepts of disease, normality and humanness?

The essays are excellent, the authors stellar - all scholars who have been writing on these issues for years. But by now, this volume is but one of many books, articles and edited collections dealing with the same broad range of issues. Indeed, they raise the very same questions that preoccupied those concerned about earlier technologies: the privacy of information in computer databanks; the personal dilemmas following from advances in clinical diagnostics that have always preceded therapeutic capabilities; the discriminatory use of tests; the age-old abuse of biology — "natural" categories - to explain and justify existing social relationships; and, of course, the notorious misuse of genetic ideas for eugenic goals.

It seems pertinent to ask whether 20 years of speculation about these problems has influenced the way we deal with advances in genetics. Has concern about the social implications of technology affected public understanding of issues such as privacy, created more sophisticated discussion in the media or resulted in more sensitive policy approaches? The record is not very promising. A recent survey exploring public attitudes towards genetic privacy found most people to be not very sensitive to the issues of confidentiality, and even willing to share genetic information (probably others', not theirs) with insurers and employers. Despite the increased use of genetic screening and awareness of the importance of genetic information, there remains a dramatic shortage of trained genetic counsellors. The media persist in oversimplified interpretations, describing the most complex human behaviour as 'programmed by the genes', treating biology as destiny and justifying gender stereotypes in terms of 'natural' traits. The appeal of reductionist explanations and technological fixes persists in the continued tendency to provide medical explanations of social problems. Some scientists themselves perpetuate misconceptions, insisting on the power of nature over nurture and promoting genetics as a cure for social pathologies as well as inherited disease.

Thomas Murray, one of the authors in Gene Mapping, makes a salient observation about the social policy discussions of the Human Genome Project: "Rarely, if ever, has something gone so swiftly from prophetic warning to cliche." The essays in this and other books have clearly been 